\title{
The use of $\mathrm{Fe}_{3} \mathrm{O}_{4} /$ Carbon composite fibers as anode materials in lithium ion batteries
}

\begin{abstract}
In the present work, results on the synthesis and mass production of polymer/ceramic composite fibers through Forcespinning ${ }^{\circledR}$ (FS) are reported. Magnetite $\left(\mathrm{Fe}_{3} \mathrm{O}_{4}\right)$, has been considered as a good anode material for Lithium-Ion Batteries (LIBs) due to its high theoretical capacity $\left(\sim 924 \mathrm{mAhg}^{-1}\right)$, low cost, and low toxicity. The $\mathrm{Fe}_{3} \mathrm{O}_{4} /$ carbon composite, in the present study, was achieved through Forcespinning iron (III) acetylacetonate /polyacrylonitrile (PAN) precursor solution with stabilization in air at $280^{\circ} \mathrm{C}$ followed by carbonization at $600^{\circ} \mathrm{C}$ under argon. The electrochemical cyclic performance of $\mathrm{Fe}_{3} \mathrm{O}_{4} / \mathrm{C}$ composite fibers was investigated by galvanostatic charge/discharge experiments. The results showed the $\mathrm{Fe}_{3} \mathrm{O}_{4} / \mathrm{C}$ composite fiber anode exhibited higher reversible capacity of $300 \mathrm{mAhg}^{-1}$ after 100 cycles at a current density of $100 \mathrm{mAg}^{-1}$ compared to that of carbon fibers, which was approximately $100 \mathrm{mAhg}^{-1}$. In addition, the $\mathrm{Fe}_{3} \mathrm{O}_{4}$ /composite fiber anode showed improved capacity retention and better rate performance than pure carbon fibers.
\end{abstract}

Volume 2 Issue 2 - 2018

\author{
Howard Campos,' Jonathon Ayala,' Carolina \\ Valdes, ${ }^{2}$ Parsons JG, ${ }^{2,3}$ Mataz Alcoutlabi,' \\ 'Department of Mechanical Engineering, University of Texas, \\ USA \\ 2Department of Chemistry, University of Texas, USA \\ ${ }^{3}$ School of Earth Environmental and Marine Sciences, University \\ of Texas, USA
}

Correspondence: Mataz Alcoutlabi, Department of Mechanica Engineering, University of Texas, Rio Grande Valley, Edinburg,TX 78539, USA, Email mataz.alcoutlabi@utrgv.edu

Received: December 28, 2017| Published: April 20, 2018

Keywords: $\mathrm{Fe}_{3} \mathrm{O}_{4}$ /composite, polymer, fibers, Forcespinning ${ }^{\circledR}$, anode, Lithium ion battery

\section{Abbreviations: \\ PAN, polyacrylonitrile; \\ PVP, polyvinylpyrrolidone; PVA, polyvinyl alcohol; DMF, N, N- dimethylformamide; $\mathrm{Fe}_{3} \mathrm{O}_{4}$, magnetite; $\mathrm{Fe}_{2} \mathrm{O}_{3}$, ferric oxide}

\section{Introduction}

Most of the current commercial LIBs use graphite as an anode material due to its long cycle life, low working potential, and low cost. But the low theoretical capacity of graphite $\left(372 \mathrm{mAhg}^{-1}\right)$ limits the effectiveness of graphite as a anode material compared to other active materials such as silicon, lithium metal, tin oxide, among other metal oxides. ${ }^{1,2}$ Most carbonaceous materials used in LIBs are processed from polymer precursors such as PAN, Polyvinylpyrrolidone (PVP) and polyvinyl alcohol (PVA). To circumvent the low capacity of the graphite anode, new anode materials have been explored such as the use of polymer-based nanostructured materials including graphene, carbon nanofibers, and composite nanofibers. ${ }^{3,4}$ Among these nanostructures, composite nanofibers have shown much promising as electrode materials for LIBs. The nanofiber structure provides high $\mathrm{Li}+$ diffusion as well as increased number of lithium storage sites. ${ }^{3}$ Polymer and polymer composite fibers are frequently produced through electrospinning, melt blowing, liquid shearing spinning, magneto spinning and Forcespinning ${ }^{\circledR}$ (FS). ${ }^{3,6,7}$ In our previous work, $\mathrm{TiO}_{2} / \mathrm{C}$, $\mathrm{Sn} / \mathrm{C}$ and $\mathrm{SnO}_{2} / \mathrm{NiO} / \mathrm{C}$ composite fibers were prepared through the FS of polymer/ceramic precursors and subsequent thermal treatments, and were directly used as anodes for LIBs. ${ }^{7-9}$ Electrospinning has been used to prepare $\mathrm{Fe}_{2} \mathrm{O}_{3}$ and $\mathrm{Fe}_{3} \mathrm{O}_{4}$ composite nano/micro fibers for LIBs electrode materials. ${ }^{10-12}$ The main goal of the present work is to use Forcespinning to produce binder free $\mathrm{Fe}_{3} \mathrm{O}_{4} / \mathrm{C}$ composite fiber anodes for LIBs. The electrochemical performance and rate performance of $\mathrm{Fe}_{3} \mathrm{O}_{4} / \mathrm{C}$ composite fiber anodes were investigated using a current density of $100 \mathrm{mAg}^{-1}$ and voltages ranging from 0.05 to $3.0 \mathrm{~V}$. To the best of our knowledge, this is the first time results on the Forcespinning of $\mathrm{Fe}_{3} \mathrm{O}_{4} / \mathrm{C}$ composite fibers for use as anodes in LIBs has been reported.

\section{Experimental study}

In this work, Poly (acrylonitrile) (PAN) with an average molecular weight of $150,000 \mathrm{gmol}^{-1}, \mathrm{~N}, \mathrm{~N}$-dimethylformamide (DMF) $(\geq 99.8 \%)$, and iron (III) acetylacetonate (FeACAC) $(\geq 99.8 \%)$ were purchased from Sigma-Aldrich USA. The precursor solution consisted of 88 wt $\%$ DMF to $12 \mathrm{wt} \%$ of solute. The solute was a mixture of $85 \mathrm{wt} \%$ PAN and $15 \mathrm{wt} \%$ FeACAC. The precursor solution was prepared by adding FeACAC into DMF and mechanically stirring the mixture for up to $12 \mathrm{~h}$. The control carbon fibers were prepared using a precursor solution consisting of $12 \mathrm{wt} \%$ PAN in $88 \mathrm{wt} \%$ DMF. The microfibers prepared from the iron precursor and control precursor solutions were spun at a rotational speed of $7000 \mathrm{rpm}$. Subsequent to spinning the collected fibrous mats were dried at $120^{\circ} \mathrm{C}$ in a vacuum oven for 12 $\mathrm{h}$ to remove residual solvent. After drying, both the control PAN and PAN/FeACAC fibers were stabilized in air at $280^{\circ} \mathrm{C}$ for $4 \mathrm{~h}$, followed by carbonization under argon at $600^{\circ} \mathrm{C}$ for $6 \mathrm{~h}$ (using a heating rate of $3^{\circ} \mathrm{C} / \mathrm{min}$ ). The morphological and elemental information of the $\mathrm{Fe}_{3} \mathrm{O}_{4} / \mathrm{C}$ composite fibers and carbon fibers were evaluated using the scanning electron microscopy (SEM) and energy dispersive $\mathrm{X}$-ray spectroscopy (EDS), powder X-ray diffraction (XRD). The SEM and EDS date were collected a Sigma VP Carl Zeiss equipped with a TEAM EDS Enhanced Analysis System., and $\mathrm{x}$-ray diffraction (XRD). For the XRD data collection the $\mathrm{Fe}_{3} \mathrm{O}_{4} / \mathrm{C}$ composite fibers were ground into a fine powder and homogenized using a mortar and pestle. The powder XRD patterns for the samples were collected using a Rigaku Miniflex powder X-ray diffractometer.

The electrochemical performance of the $\mathrm{Fe}_{3} \mathrm{O}_{4} / \mathrm{C}$ composite electrodes was measured using 2032 coin-type cells. The electrolyte was a $1 \mathrm{M}$ solution of LiPF6 salt in ethylene carbonate (EC)/dimethyl carbonate (DMC) with a 1:1 v/v ratio. The cells were assembled in a glove box (MBraun, USA) under argon. The electrochemical performance was evaluated using galvanostatic charge-discharge experiments at a current density of $100 \mathrm{mAg}^{-1}$ with the voltage ranging between $0.05 \mathrm{~V}$ and $3 \mathrm{~V}$. 


\section{Results and discussion}

Figure 1 shows the SEM images collected from the control and $\mathrm{Fe}_{3} \mathrm{O}_{4} / \mathrm{C}$ composite microfibers. The average diameter observed for the control microfibers (Figure 1A) was determined to be $3.02 \pm 0.37 \mu \mathrm{m}$. Elemental mapping analysis (EDS) showed that the fibers consisted of carbon (Figure 1B). The $\mathrm{Fe}_{3} \mathrm{O}_{4} / \mathrm{C}$ composite microfibers (Figure $1 \mathrm{C}-1 \mathrm{E})$ showed a slightly larger average diameter of $3.26 \pm 0.16 \mu \mathrm{m}$. The presence of iron in the $\mathrm{Fe}_{3} \mathrm{O}_{4} / \mathrm{C}$ microfiber matrix can be seen in the EDS map of the sample (Figure 1D). The dispersion of the iron within the carbon fiber was confirmed by EDS mapping of Fe as can be seen in Figure 1E. There were no observable continuous bright spots in the iron map, indicating the iron was dispersed throughout the sample.

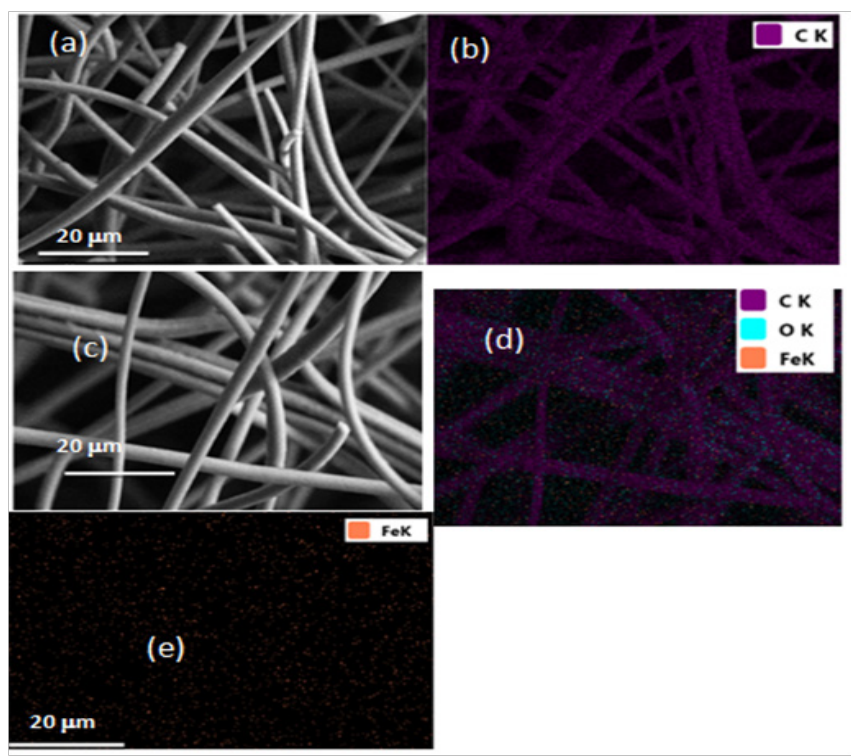

Figure I (A,B) SEM and Elemental mapping of the carbon microfibers. (C, D and $\mathrm{E}) \mathrm{Fe}_{3} \mathrm{O}_{4} / \mathrm{C}$ composite microfibers.

Figure 2 shows the collected XRD data, the Full prof Lebail fitting of the sample, the difference between the fitting and the sample data, as well as the Bragg peaks for the synthesized $\mathrm{Fe}_{3} \mathrm{O}_{4} / \mathrm{C}$ microfibers. As can be seen in Figure 2, there is very little difference between the fitting and the actual XRD data as indicated by the small residual in the difference pattern. ${ }^{13,14}$ The small residual between the fitting and the data indicates that the iron present in the sample is $\mathrm{Fe}_{3} \mathrm{O}_{4}$. The amorphous nature of the carbon present in the sample did not allow for the fitting of the carbon phase. The Bragg peaks shown in the diffraction pattern at $18.28,30.08,35.43,37.06,43.05,47.14,53.41$, 56.93 , and $56.93^{\circ}$ in $2 \theta$ correspond to the $111,220,311,222,400$, $331,422,333$, and 511 diffraction planes consistent with the Fd3M crystal structure of magnetite. ${ }^{15}$

Figure $3 \mathrm{~A} \&$ Figure $3 \mathrm{~B}$ show the charge/discharge profile of the control fibers and the $\mathrm{Fe}_{3} \mathrm{O}_{4} / \mathrm{C}$ composite fibers at $100 \mathrm{mAg}^{-1}$, respectively. The initial discharge capacity for the $\mathrm{Fe}_{3} \mathrm{O}_{4} / \mathrm{C}$ composite fibers was $915 \mathrm{mAhg}^{-1}$ which is much higher than the discharge capacity of the control fibers $\left(507 \mathrm{mAhg}^{-1}\right)$. The charge capacities ( $\mathrm{Li}-$ deinsertion) at the 1 st cycle for the control and $\mathrm{Fe}_{3} \mathrm{O}_{4} / \mathrm{C}$ composite fibers were $98 \mathrm{mAg}^{-1}$ and $333 \mathrm{mAg}^{-1}$ which resulted in initial Columbic efficiencies of $20 \%$ and $37 \%$, respectively. The wide variance in the initial charge and discharge capacities for the $\mathrm{Fe}_{3} \mathrm{O}_{4} / \mathrm{C}$ composite fibers has been observed in $\mathrm{Li}$-ion batteries and is primarily attributed to the formation of the SEI layer during the first cycle and the high surface area to volume ratio observed in microfibers. The capacity recovery for the control fibers was minimal and was observed between the initial charge and 100th discharge cycles. At the end of the 100th cycle, the charge capacities were observed to be $127 \mathrm{mAhg}^{-1}$ for the control fibers and $328 \mathrm{mAhg}^{-1}$ for the $\mathrm{Fe}_{3} \mathrm{O}_{4} / \mathrm{C}$ composite fibers. In addition, the control fibers were observed to suffer from a high loss in capacity at the first cycle, which can be attributed to the high surface area of the fibers and the formation of the SEI layer.
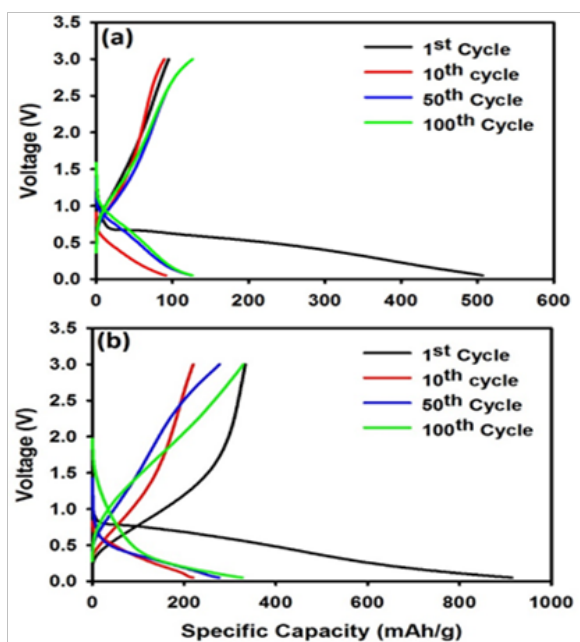

Figure 2 X-ray diffraction data and fitting of the synthesized $\mathrm{Fe} 3 \mathrm{O} 4 / \mathrm{C}$ composite microfibers.

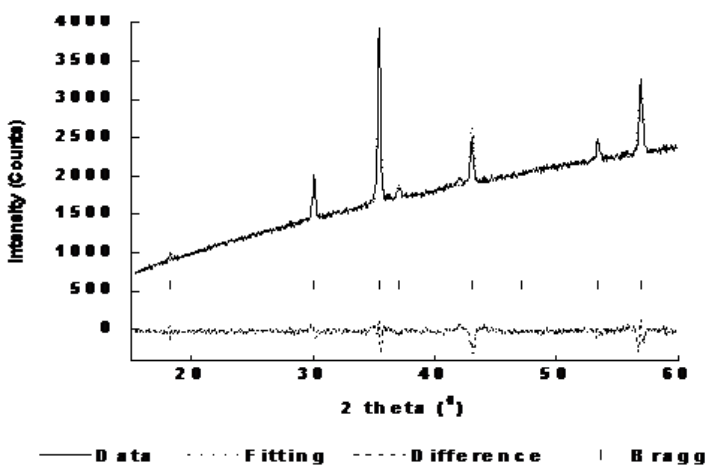

Figure 3 (A) Charge/Discharge profiles for carbon fibers. (B) $\mathrm{Fe}_{3} \mathrm{O}_{4} / \mathrm{C}$ composite fibers carried out at a current density of $100 \mathrm{mAg}^{-1}$.

The rate performance of the carbon and $\mathrm{Fe}_{3} \mathrm{O}_{4} / \mathrm{C}$ composite fibers was evaluated by carrying out charge/discharge experiments for 10 cycles at current densities of 50,100, 200, 400, and $500 \mathrm{mAg}^{-1}$ and recycled back at $50 \mathrm{mAg}^{-1}$. The results of the rate performance are presented in Figure 4A \& Figure 4B for the control fibers and the $\mathrm{Fe}_{3} \mathrm{O}_{4} / \mathrm{C}$ composite fibers, respectively. Both the carbon and $\mathrm{Fe}_{3} \mathrm{O}_{4} / \mathrm{C}$ composite fiber electrodes showed capacity recovery when the anodes were cycled at an initial current density of $50 \mathrm{mAg}^{-1}$. The carbon fibers and $\mathrm{Fe}_{3} \mathrm{O}_{4} / \mathrm{C}$ composite fibers-delivered a charge capacity of $160 \mathrm{mAhg}^{-1}$ and $268 \mathrm{mAhg}^{-1}$ after 10 cycles at $50 \mathrm{mAg}$ ${ }^{1}$, respectively. The discharge capacities of the carbon and $\mathrm{Fe}_{3} \mathrm{O}_{4} / \mathrm{C}$ composite fibers show degradation at high current density of 400 and $500 \mathrm{mAg}^{-1}$. Furthermore, a degradation in the reversible capacity was observed when the anodes were cycled back at $50 \mathrm{mAg}^{-1}$, resulting 
in reversible capacities of 124 and $306 \mathrm{mAg}^{-1}$, for the carbon and $\mathrm{Fe}_{3} \mathrm{O}_{4} / \mathrm{C}$ electrodes, respectively. The $\mathrm{Fe}_{3} \mathrm{O}_{4} / \mathrm{C}$ composite electrode shows improved rate performance, compared to the control $\mathrm{C}$-fibers at low current densities and high capacity recovery after 60 cycles.
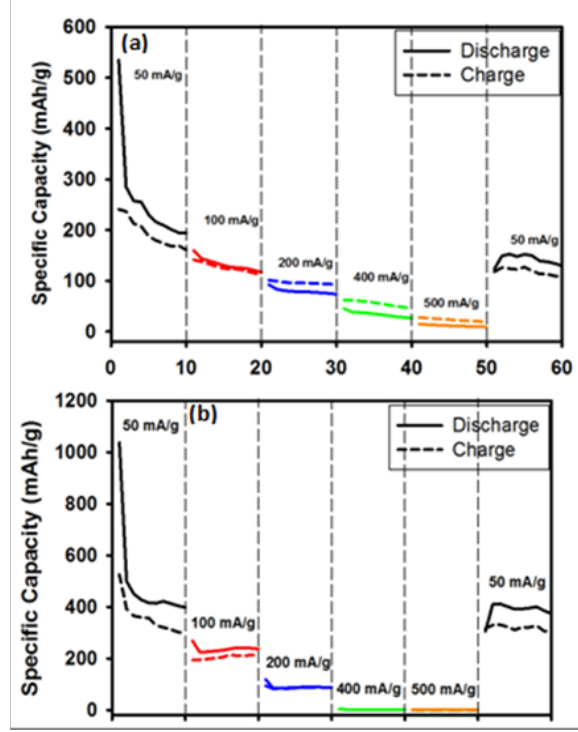

Figure 4 Rate performance for carbon fibers (top) and $\mathrm{Fe}_{3} \mathrm{O}_{4} / \mathrm{C}$ composite fibers (bottom) carried out at different current densities of 50, 100, 200, 400, and $500 \mathrm{mAg}^{-1}$.

\section{Conclusion}

$\mathrm{Fe}_{3} \mathrm{O}_{4} / \mathrm{C}$ composite fibers and carbon fibers were prepared by Forcespinning and subsequent thermal treatments and were directly used as binder-free anodes for LIBs. The electrochemical performance of the $\mathrm{Fe}_{3} \mathrm{O}_{4} / \mathrm{C}$ composite fibers showed improved cycling stability, enhanced specific capacity, good capacity retention as well as capacity recovery over 100 cycles. To the authors' knowledge this is the first report results on the synthesis of $\mathrm{Fe}_{3} \mathrm{O}_{4} / \mathrm{C}$ composite fibers using FS in combination with a solvo thermal method for applications in LIBs. The use of the FS shows high potential to yield a high amount of fibers in a short period of time, potentially increasing production rates. The processing method discussed in this work could be widely applied for the large production rate of binder-free composite fiber electrodes for a wide range of applications including Lithium-ion and sodium ion batteries, and supercapacitors.

\section{Acknowledgements}

This research was supported by the USDA, the National Institute of Food and Agriculture, and the Integrating Food Science/Engineering and Education Network (IFSEEN) with award number: 2015-3842224059. This research was also supported by NSF PREM with award number DMR-1523577. Dr. J.G. Parsons acknowledges financial support from the Welch Foundation for supporting the Department of Chemistry (Grant number GB-0017).

\section{Conflict of interest}

The author declares there is no conflict of interest.

\section{References}

1. Zhang WM, Wu XL, Hu JS, et al. Carbon Coated $\mathrm{Fe}_{3} \mathrm{O}_{4}$ Nanospindles as a Superior Anode Material for Lithium-Ion Batteries. Advanced Functional Materials. 2008;18(24):3941-3946.

2. Goodenough JB, Kim Y. Challenges for Rechargeable Li Batteries. Chemistry of Materials. 2010;22(3):587-603.

3. Wang ZY, Zhou L, Lou XW. Metal Oxide Hollow Nanostructures for Lithium-ion Batteries. Advanced Materials. 2012;24(14):1903-1911.

4. Liwen Ji, Zin L, Alcoutlabi M, et al. Recent developments in nanostructured anode materials for rechargeable lithium-ion batters. Energy \& Environmental Science. 2011;4(8):2682-2699.

5. Etacheri V, Marom R, Elazari R, et al. Challenges in the development of advanced Li-ion batteries: a review. Energy \& Environmental Science. 2011;4(9):3243-3262.

6. Swiatek J, Jarzebowski J, Cichon J. Investigation of Fibre Diameter Distribution in Non-Woven Textiles for Medical Applications in MeltBlown Polyester Technology. Fibres \& Textiles in Eastern Europe. 2008;16(3):14-16.

7. Agubra VA, Zuniga L, De la Garza D, et al. Forcespinning: A new method for the mass production of $\mathrm{Sn} / \mathrm{C}$ composite nanofiber anodes for lithium ion batteries. Solid State Ionics. 2016;286:72-82.

8. Agubra VA, Zuniga L, Flores D, et al. A comparative study on the performance of binary $\mathrm{SnO}_{2} / \mathrm{NiO} / \mathrm{C}$ and $\mathrm{Sn} / \mathrm{C}$ composite nanofibers as alternative anode materials for lithium ion batteries. Electrochimica Acta. 2017;224:608-621.

9. Zuniga L, Agubra VA, Flores D, et al. Multichannel hollow structure for improved electrochemical performance of $\mathrm{TiO}_{2} /$ Carbon composite nanofibers as anodes for lithium ion batteries. Journal of Alloys and Compounds. 2016;686:733-743.

10. Wu CY, $\mathrm{Li} \mathrm{X}, \mathrm{Li} \mathrm{W}$, et al. $\mathrm{Fe}_{2} \mathrm{O}_{3}$ nanorods/carbon nanofibers composite: Preparation and performance as anode of high rate lithium ion battery. Journal of Power Sources. 2014;251:85-91.

11. Wang HG, Zhou T, Shen Y, et al. Fabrication, formation mechanism and the application in lithium-ion battery of porous $\mathrm{Fe}_{2} \mathrm{O}_{3}$ nanotubes via single-spinneret electrospinning. Electrochimica Acta. 2016;158:105-112.

12. Ji L, Toprakci O, Alcoutlabi M, et al. $\alpha-\mathrm{Fe}_{2} \mathrm{O}_{3}$ Nanoparticle-Loaded Carbon Nanofibers as Stable and High-Capacity Anodes for Rechargeable LithiumIon Batteries. Acs Applied Materials \& Interfaces. 2012;4(5):2672-2679.

13. Le Bail A, Duroy H, Fourquet JL. Ab-Initio Structure Determination of LiSbWO8 By X-Ray Powder Diffraction. Mat Res Bull. 1988;23:447-452.

14. Rodríguez-Carvajal J. FULLPROF: A Program for Rietveld Refinement and Pattern Matching Analysis. Abstracts of the Satellite Meeting on Powder Diffraction of the XV Congress of the IUCr. 1990. $127 \mathrm{p}$.

15. Fleet ME. The structure of Magnetite. Acta Cryst. 1981;B37:917-920. 